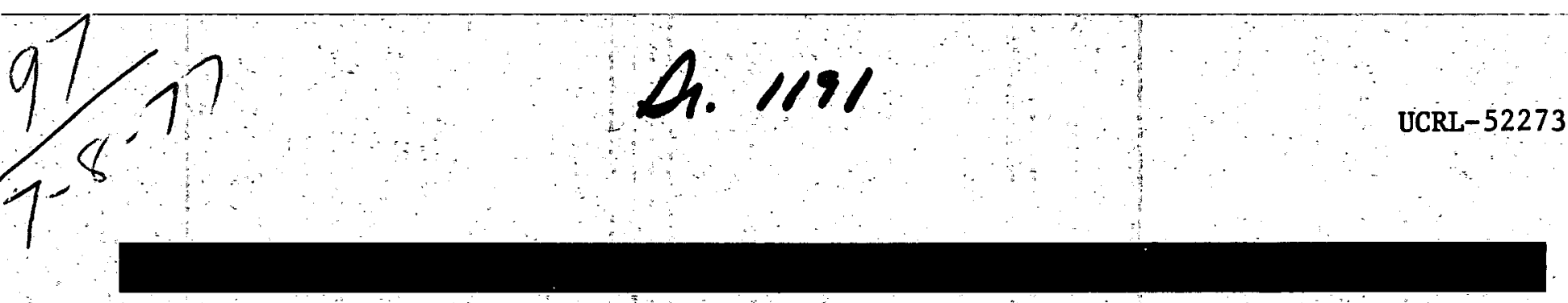

\title{
SHOCK INITIATION OF PBXN-5 AND PBX-96.04
}

\author{
L. G: $=$ Green \\ E. J. Nidick, Jr. \\ J. D. Longwith
}

Apri1 29, 1977

Prepared for U.S. Energy Research \& Development Administration under contract No. W-7405-Eng-48

\section{4 \\ I AWRENCE LIVERMORE LABORATORY}

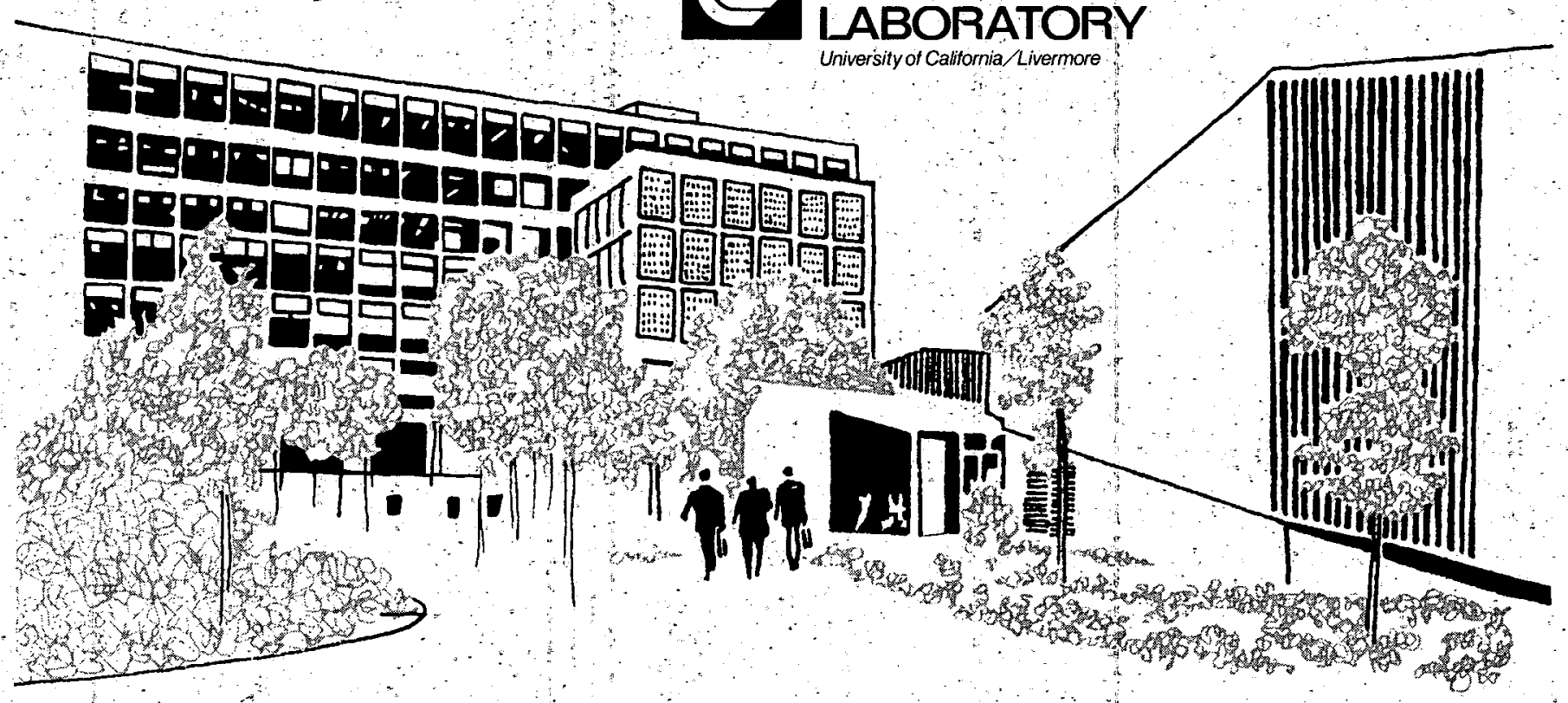




\section{DISCLAIMER}

This report was prepared as an account of work sponsored by an agency of the United States Government. Neither the United States Government nor any agency Thereof, nor any of their employees, makes any warranty, express or implied, or assumes any legal liability or responsibility for the accuracy, completeness, or usefulness of any information, apparatus, product, or process disclosed, or represents that its use would not infringe privately owned rights. Reference herein to any specific commercial product, process, or service by trade name, trademark, manufacturer, or otherwise does not necessarily constitute or imply its endorsement, recommendation, or favoring by the United States Government or any agency thereof. The views and opinions of authors expressed herein do not necessarily state or reflect those of the United States Government or any agency thereof. 


\section{DISCLAIMER}

Portions of this document may be illegible in electronic image products. Images are produced from the best available original document. 


\section{NOTICE}

This report was prepared as an account of work sponsored by the United States Government. Neither the United States nor the United States Energy Research \& Development Administration, nor any of their employees, nor any of their contractors, subcontractors, or their employees, makes any warranty, express or implied, or assumes any legal liability or responsibility. for the accuracy, completeness or usefulness of any information, apparatus, product or process disclosed, or represents that its use would not infringe privately-owned rights.

\section{NOTICE}

Reference to a company or product name does not imply approval or recommendation of the product by the University of California or the U.S. Energy Research \& Development Administration to the exclusion of others that may be suitable.

Printed in the United States of America Available from

National Technical Information Service

U.S. Department of Commerce

5285 Port Royal Road

Springfield, VA 22161

Price: Printed Copy $\$$; Microfiche $\$ 3.00$

\begin{tabular}{|c|c|c|c|}
\hline Page Range & $\begin{array}{c}\text { Domestic } \\
\text { Price }\end{array}$ & Page Range & $\begin{array}{c}\text { Domestic } \\
\text { Price }\end{array}$ \\
\hline $001-025$ & $\$ 3.50$ & $326-350$ & 10.00 \\
\hline $026-050$ & 4.00 & $351-375$ & 10.50 \\
\hline $051-075$ & 4.50 & $376-400$ & 10.75 \\
\hline $076-100$ & 5.00 & $401-425$ & 11.00 \\
\hline $101-125$ & 5.50 & $426-450$ & 11.75 \\
\hline $126-150$ & 6.00 & $451-475$ & 12.00 \\
\hline $151-175$ & 6.75 & $476-500$ & 12.50 \\
\hline $176-200$ & 7.50 & $501-525$ & 12.75 \\
\hline $201-225$ & 7.75 & $526-550$ & 13.00 \\
\hline $226-250$ & 8.00 & $551-575$ & 13.50 \\
\hline $251-275$ & 9.00 & $576-600$ & 13.75 \\
\hline $276-300$ & 9.25 & $601-u p$ & $*$ \\
\hline $301-325$ & 9.75 & & \\
\hline
\end{tabular}

*Add $\$ 2.50$ for éach additional 100 page increment from 601 to 1.000 pages; add $\$ 4,50$ for each additional 100 page increment over 1,000 pages. 
Distribution Category $\mathrm{UC}-45$

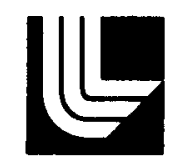

\section{LAWRENCE LIVERMORE LABORATORY}

University of Caltornia/Livermore, California/ 94550

UCRL-52273

\section{SHOCK INITIATION OF PBXN-5 AND PBX-9604}

L. G. Green

E. J. Nidick, Jr.

J. D. Longwith

MS. date: April 29, 1977

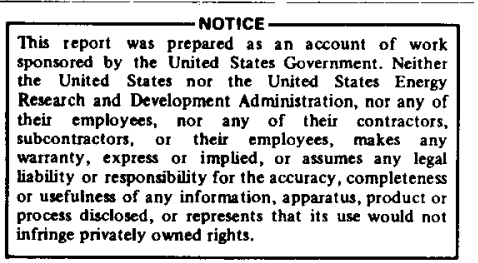




\section{Preface}

This report was prepared for the Department of the Army, Harry Diamond Laboratories, Adelphi, Maryland 20783, HDL Project A77646, under the auspices of the U.S. Energy Research \& Development Administration under contract No. W-7405-Eng-48. 


\section{Contents}

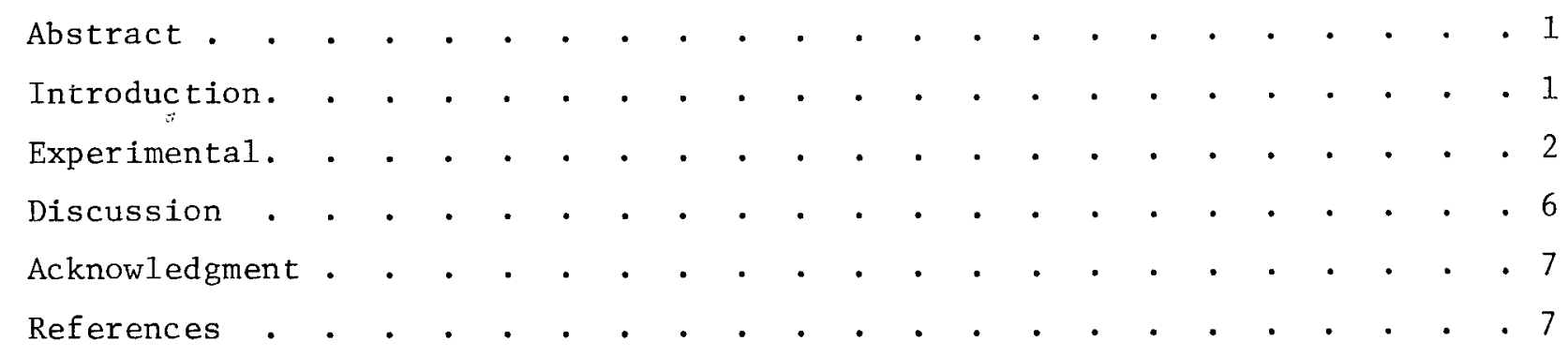




\section{SHOCK INITIATION OF PBXN-5 AND PBX-9604}

\section{Abstract}

The PBXN-5 and PBX-9604 shock Hugoniots, 1ongitudinal and shear sound velocities, and response to long and short duration shocks have been determined. At a density of $1.66 \mathrm{Mg} / \mathrm{m}^{3}, \mathrm{PBXN}-5$ requires a minimum copper f1yer kinetic energy of $382 \mathrm{~kJ} / \mathrm{m}^{2}$ for initiation at a flyer velocity of $0.8 \mathrm{~km} / \mathrm{s}$. At a density of $1.49 \mathrm{Mg} / \mathrm{m}^{3}, \mathrm{PBX}-9604$ requires a minimum flyer energy of $201 \mathrm{~kJ} / \mathrm{m}^{2}$ for initiation at the same velocity.

\section{Introduction}

We have determined the experimental response of $\mathrm{PBXN}-5^{*}$ and $\mathrm{PBX}-9604^{\dagger}$ to strong shocks. The initiation experiments included both long (3- $\mu s)$ and short $(<0.1-\mu s)$ duration shocks. Shock Hugoniot data were obtained from symmetrical impacts of explosive on explosive. Longitudinal and shear sound velocities were obtained from ultrasonic measurements.

PBXN-5 Type I MIL-E-81111A(os) was purchased from the Naval Ships Parts Control Center, Mechanicsburg, Pennsylvania. Thermal analysis showed no unexpected behavior. PBX-9604 was prepared at Lawrence Livermore Laboratory (LLL) according to a procedure outlined by Walker. ${ }^{1}$ We found that PBX-9604 is the same as an experimental formulation prepared at LLL 10 or 15 years ago and known then as $\mathrm{RX}-10-\mathrm{AB}$. The latter was not pursued at that time, presumably because of the superior mechanical strength and pressability of $\mathrm{PBX}-9407$, ** which was also available, and because of its very small gain in sensitivity over PBX-9407. There was also some fear that the low percentage of binder in RX-10-AB might cause a dust problem in automatic loading equipment.

${ }^{* *} \mathrm{PBX}-9407$ is $94 / 6 \mathrm{RDX} /$ Exon 461. 


\section{Experimental}

The principal features of sustainedpulse, shock-initiation experiments with the 101.6-mm gun have been described elsewhere. ${ }^{2,3}$ The current experiments differed from previous ones in that the explosive samples were only $25.4 \mathrm{~mm}$ in diameter and were impacted four at a time. A typical experiment consisted of impacting a group of four explosive samples with a thick (6-mm), copper, gun-propelled flyer plate and timing the transit of the shock wave plus detonation through these samples. Excess transit time (XSTT) was then calculated, where XSTT is defined as the observed transit time of the shock plus detonation minus the calculated time for transit of the detonation through the same thickness of explosive. Impact pressure was calculated from the velocity of the flyer, the known Hugoniot equation of state of the flyer, and the measured Hugoniot equation of state of the explosive being tested. Results were then plotted as the $10 \mathrm{~g}$ of the XSTT versus the $\log$ of the initiating pressure, an approximately linear relationship reported by Ramsay and Popolato. ${ }^{4}$ Results from the tests on PBXN-5 and PBX-9604 are summarized in Fig. 1.

As the foil thickness (and the energy per unit area) is reduced, the XSTT observed will increase until the

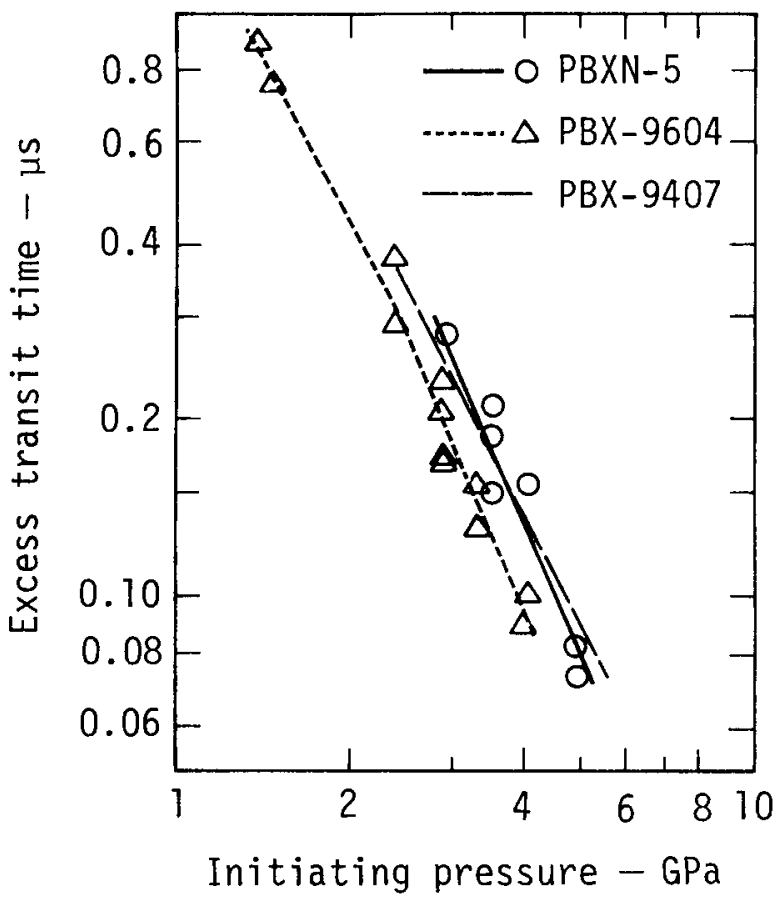

Fig. 1. Excess transit time versus sustained-pulse initiating pressure for PBXN-5, PBX-9604, and PBX-9407. Data for PBX-9407 are from Lindstrom. 6 Note similarity between PBX-9407 and PBXN-5 data.

detonation fails to propagate. Shortpulse initiation experiments therefore consist of thin-foil experiments tailored to give at least twice the XSTT that a comparable thick-plate experiment would give. The minimum or "critical" energy of initiation, $E_{c}$, is calculated from the empirical equation ${ }^{2}$

$$
(X-1)\left(Y-E_{C}\right)=C,
$$

where $\mathrm{X}$ is the reduced XSTT, $\mathrm{Y}$ is the kinetic energy of the flyer plate per 
unit area, and $\mathrm{C}$ is a constant that varies from one explosive to another. Reduced XSTT is the observed XSTT from a particular short-pulse experiment divided by the XSTT that would have resulted from a comparable sustainedpulse experiment. Ideally, only experiments where the reduced XSTT exceeds two are used to estimate minimum initiation energy.

For the short-pulse initiation experiments, we used the same 101.6-mm gun and general experimental layout as for the sustained-pulse experiments; however, the flyer was a carbon-foam-backed copper foil ${ }^{5}$ instead of a thick (6-mm) copper plate. Results from all short-pulse, energylimited, initiation experiments on PBXN-5 and PBX-9604 are summarized in Tables 1 and 2 .

For the Hugoniot equation-of-state experiments, we used the same 101.6-mm gun facility as for the other

Table 1. Results of the short-pulse (energy-limited) initiation experiments on PBXN-5 (using a copper flyer plate).

\begin{tabular}{|c|c|c|c|c|c|c|c|}
\hline $\begin{array}{l}\text { Density } \\
\text { of } \\
\text { explosive } \\
\left(\mathrm{Mg} / \mathrm{m}^{3}\right)\end{array}$ & $\begin{array}{c}\text { Flyer } \\
\text { plate } \\
\text { thickness } \\
(\mathrm{mm})\end{array}$ & $\begin{array}{c}\text { Impact } \\
\text { velocity } \\
(\mathrm{km} / \mathrm{s})\end{array}$ & $\begin{array}{c}\text { Initial } \\
\text { pressure } \\
(\mathrm{GPa})\end{array}$ & $\begin{array}{c}\text { Flyer } \\
\text { plate } \\
\text { kinetic } \\
\text { energy } \\
\left(\mathrm{kJ} / \mathrm{m}^{2}\right)\end{array}$ & & $\begin{array}{c}\text { Excess } \\
\text { transit } \\
\text { time } \\
(\mu s)\end{array}$ & $\begin{array}{l}\text { Minimum } \\
\text { flyer } \\
\text { energy for } \\
\text { initiation } \\
\quad\left(\mathrm{kJ} / \mathrm{m}^{2}\right)\end{array}$ \\
\hline 1.658 & 0.127 & 0.798 & 3.62 & 361 & No & det., $11 \mathrm{~mm}$ & $>361$ \\
\hline 1.661 & .127 & .798 & 3.62 & 361 & No & det., $7.5 \mathrm{~mm}$ & $>361$ \\
\hline 1.660 & .132 & .793 & 3.60 & 371 & No & det., $11 \mathrm{~mm}$ & $>371$ \\
\hline 1.664 & .132 & .793 & 3.60 & 371 & No & det., $7.5 \mathrm{~mm}$ & $>371$ \\
\hline 1.665 & .132 & .793 & 3.60 & 371 & No & $\operatorname{det} ., 11 \mathrm{~mm}$ & $>371$ \\
\hline 1.666 & .132 & .793 & 3.60 & 371 & No & $\operatorname{det} ., \quad 7.5 \mathrm{~mm}$ & $>371$ \\
\hline 1.658 & .137 & .788 & 3.55 & 380 & No & $\operatorname{det} ., \quad 7.5 \mathrm{~mm}$ & $>380$ \\
\hline 1.658 & .137 & .788 & 3.55 & 380 & No & $\operatorname{det} ., 11 \mathrm{~mm}$ & $>380$ \\
\hline 1.666 & .137 & .788 & 3.55 & 380 & No & det., $7.5 \mathrm{~mm}$ & $>380$ \\
\hline 1.667 & .137 & .788 & 3.55 & 380 & No & det., $11 \mathrm{~mm}$ & $>380$ \\
\hline 1.660 & .141 & .805 & 3.67 & 407 & & 0.605 & 358 \\
\hline 1.663 & .141 & .805 & 3.67 & 407 & & 0.778 & 372 \\
\hline 1.658 & .157 & .800 & 3.63 & 450 & & 0.552 & 392 \\
\hline \multirow[t]{2}{*}{1.660} & 0.157 & 0.800 & 3.64 & 450 & & 0.665 & 406 \\
\hline & & & & & & Best value & 382 \\
\hline
\end{tabular}


experiments. A 3.2-mm-thick disk of target explosive was impacted by a disk of the same explosive propelled down the gun barrel in a sabot. We measured the transit time of the shock and calculated the average shock velocity. Particle velocity after impact was taken as half of the projectile velocity. The shock velocity at zero particle velocity was taken as the bulk sound velocity $\mathrm{C}_{0}$ calculated from the ultrasonic longitudinal sound velocity $\mathrm{C}_{1}$ and shear sound velocity $\mathrm{C}_{\mathrm{S}}$ by the equation

Table 2. Results of the short-pulse (energy-limited) initiation experiments on PBX-9604 (using a copper flyer plate).

\begin{tabular}{|c|c|c|c|c|c|c|}
\hline $\begin{array}{l}\text { Density } \\
\text { of } \\
\text { explosive } \\
\left(\mathrm{Mg} / \mathrm{m}^{3}\right)\end{array}$ & $\begin{array}{c}\text { Flyer } \\
\text { plate } \\
\text { thickness } \\
(\mathrm{mm})\end{array}$ & $\begin{array}{c}\text { Impact } \\
\text { velocity } \\
(\mathrm{km} / \mathrm{s})\end{array}$ & $\begin{array}{l}\text { Initial } \\
\text { pressure } \\
\text { (GPa) }\end{array}$ & $\begin{array}{c}\text { F1yer } \\
\text { plate } \\
\text { kinetic } \\
\text { energy } \\
\left(\mathrm{kJ} / \mathrm{m}^{2}\right)\end{array}$ & $\begin{array}{c}\text { Excess } \\
\text { transit } \\
\text { time } \\
(\mu s)\end{array}$ & $\begin{array}{l}\text { Minimum } \\
\text { flyer } \\
\text { energy for } \\
\text { initiation } \\
\quad\left(\mathrm{kJ} / \mathrm{m}^{2}\right)\end{array}$ \\
\hline 1.490 & 0.084 & 0.806 & 3.02 & 243 & 1.146 & 219 \\
\hline 1.493 & .084 & .806 & 3.02 & 243 & 0.952 & 213 \\
\hline 1.488 & .089 & .805 & 3.01 & 257 & 0.603 & 202 \\
\hline 1.491 & .089 & .805 & 3.01 & 257 & 0.456 & 173 \\
\hline 1.491 & .089 & .805 & 3.01 & 257 & 0.538 & 192 \\
\hline 1.492 & .089 & .805 & 3.01 & 257 & 0.575 & 198 \\
\hline 1.487 & .102 & .812 & 3.05 & 299 & 0.367 & 179 \\
\hline 1.490 & .102 & .812 & 3.05 & 299 & 0.420 & 205 \\
\hline 1.492 & .102 & .812 & 3.05 & 299 & 0.494 & 228 \\
\hline 1.492 & .102 & .812 & 3.05 & 299 & 0.401 & 198 \\
\hline 1.489 & .127 & .798 & 2.97 & 361 & 0.371 & 226 \\
\hline 1.492 & .141 & .805 & 3.02 & 407 & 0.349 & 263 \\
\hline 1.493 & .141 & .805 & 3.02 & 407 & 0.291 & 186 \\
\hline 1.487 & .157 & .800 & 2.98 & 450 & 0.279 & 178 \\
\hline 1.489 & 0.157 & 0.800 & 2.98 & 450 & 0.319 & 261 \\
\hline
\end{tabular}


Table 3. Results of Hugoniot experiments on PBXN-5 and PBX-9604. Zero particle velocity shock velocity data is calculated from ultrasonic longitudinal and shear velocity measurements.

\begin{tabular}{|c|c|c|c|c|}
\hline Explosive & $\begin{array}{c}\text { Particle } \\
\text { velocity, } \mathrm{U}_{\mathrm{p}} \\
(\mathrm{km} / \mathrm{s})\end{array}$ & $\begin{array}{c}\text { Measured shock } \\
\text { velocity, } U_{\mathrm{s}} \\
(\mathrm{km} / \mathrm{s})\end{array}$ & $\begin{array}{c}\text { Density of } \\
\text { target explosive } \\
\left(\mathrm{Mg} / \mathrm{m}^{3}\right)\end{array}$ & $\begin{array}{c}\text { Density of } \\
\text { f1yer explosive } \\
\left(\mathrm{Mg} / \mathrm{m}^{3}\right)\end{array}$ \\
\hline \multirow[t]{6}{*}{ PBXN-5 } & 0 & 1.133 & 1.661 & - \\
\hline & 0 & 1.220 & 1.662 & - \\
\hline & 0.329 & 2.112 & 1.659 & 1.661 \\
\hline & 0.403 & 2.267 & 1.661 & 1.667 \\
\hline & 0.432 & 2.394 & 1.661 & 1.666 \\
\hline & 0.479 & 2.506 & 1.660 & 1.666 \\
\hline \multirow[t]{5}{*}{ PBX-9604 } & 0 & 0.996 & 1.491 & - \\
\hline & 0 & 0.967 & 1.488 & - \\
\hline & 0.298 & 1.704 & 1.491 & 1.493 \\
\hline & 0.299 & 1.810 & 1.495 & 1.491 \\
\hline & 0.397 & 1.950 & 1.489 & 1.489 \\
\hline
\end{tabular}

Results are summarized in Table 3 and also in Fig. 2, along with a leastsquares fit to the data. The points calculated from the ultrasonic data were given equal weight with the other data points.

Fig. 2. Shock velocity $U_{s}$ versus particle velocity $U$ for $\mathrm{PBXN}-5$ and PBX-9604. The bulk $\mathrm{p}$ sound velocity Co has been taken as the intercept of the shock velocity axis. The PBXN-5 data may be represented by the equation $\mathrm{U}_{\mathrm{s}}=1.178$

$+2.779 \mathrm{U} \mathrm{km} / \mathrm{s}$; that for PBX-9604 by $U_{\mathrm{s}}=0.987+2.509 \mathrm{U}_{\mathrm{p}} \mathrm{km} / \mathrm{s}$.

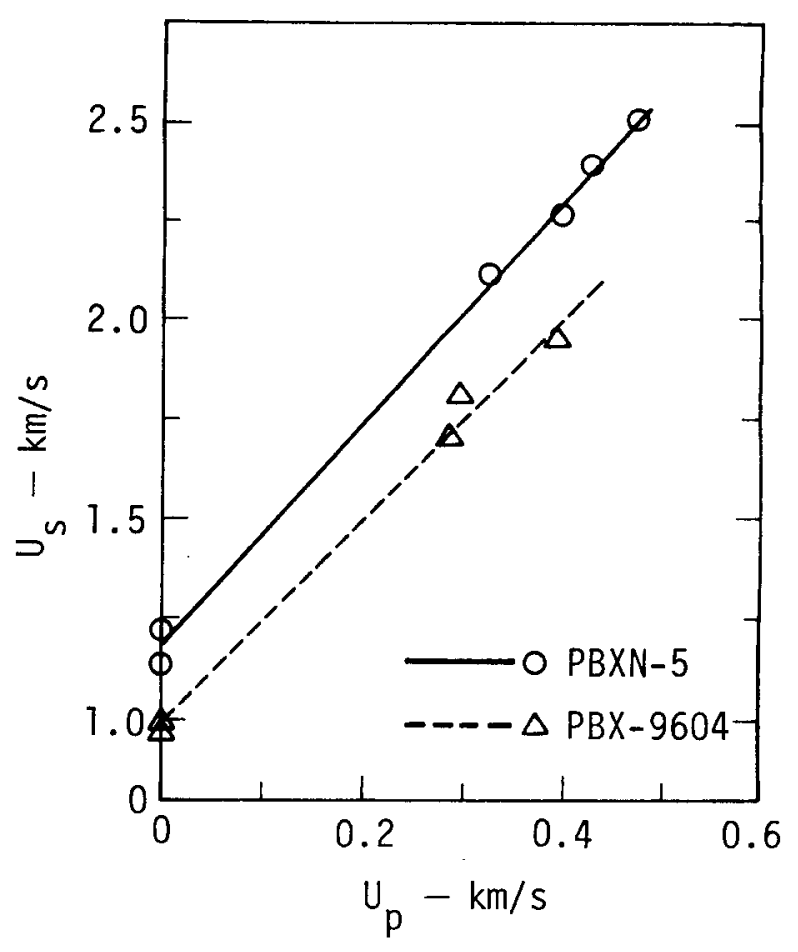




\section{Discussion}

PBX-9604 is more sensitive than PBXN-5 to both sustained-pulse initiation and to energy-limited, short-pulse initiation. It appears that the higher percentage of voids in $\mathrm{PBX}-9604(17.9 \%)$ at its working density compared to that in $\mathrm{PBXN}-5$ $(12.3 \%)$ at its working density is largely responsible for the difference observed in the sustained-pulse experiments. PBX-9407, which is made with the same kind of RDX as PBX-9604 but which has only an $11.1 \%$ void volume as it is normally used, has about the same sensitivity to sustained-pulse initiation as $\mathrm{PBXN}-5{ }^{6}$ It should be noted that the sustained-pulse experiments measure the rate of buildup of detonation in an explosive from a given stimulus, while the energylimited, short-pulse experiments measure the minimum stimulus that will still result in detonation. Thus, the percentage of voids has a large influence on the rate of buildup of detonation.

The intrinsic sensitivity of the explosive (as opposed to the sensitivity due to voids) appears to be responsible for a large fraction of the sensitivity to short-pulse initiation. PBX-9407 at its normal working density requires the flyer to have a kinetic energy of about $277 \mathrm{~kJ} / \mathrm{m}^{2}$ (Ref. 7), which is closer to the $202 \mathrm{~kJ} / \mathrm{m}^{2}$ required for $\mathrm{PBX}-9604$ than it is to the $382 \mathrm{~kJ} / \mathrm{m}^{2}$ required for PBXN-5, even though the sensitivity of PBX-9407 to sustained-pulse initiation is similar to that of $\mathrm{PBXN}-5$. Thus, the similar intrinsic sensitivity of the RDX in PBX-9604 and PBX-9407 results in their similar sensitivity to a short-pulse initiation. Because the percentage of voids has some effect, PBX-9604 is more sensitive than $\mathrm{PBX}-0407$ even though made from the same kind of $\mathrm{RDX}$.

As a final comment, we should mention that minimum or critical energy for initiation is pressure dependent for some (if not most) explosives. 3,8 The very wide pressure range of constant critical energy for PBX-9404 reported by Walker and Wasley ${ }^{9}$ may be more the exception than the rule. The pressure dependencies of the critical or minimum initiation energies for PBXN-5 and PBX-9604 were not determined in these experiments. 


\section{Acknowledgment}

The authors would like to express their gratitude and appreciation to $W$. Mumper, M. Bainter, and W. Duguid for their help with the $101.6-\mathrm{mm}$ gun; to A.
Brown and D. Green for their help with the ultrasonic measurements; and to $\mathrm{W}$. Gummer and G. Moody for preparing the PBX-9604 used in these experiments.

\section{References}

1. Letter, R. F. Walker, Chief Explosives Division, Feltman Research Laboratory, to R. K. Warner, Harry Diamond Laboratories (May 18, 1976).

2. L. G. Green, E. J. Nidick, Jr., and F. E. Walker, Critical Shock Initiation Energy of PBX-9404, A New Approach, Lawrence Livermore Laboratory, Rept. UCRL-51522 (1974).

3. R. K. Jackson, L. G. Green, R. H. Barlett, W. W. Hofer, P. E. Kramer, R. S. Lee, E. J. Nidick, Jr., L. L. Shaw, and R. C. Weingard, "Initiation and Detonation Characteristics of TATB," in Proc Sixth Int. Symp. Detonation, San Diego, CA, 1976 (ONR, NSWC, LASL, LLL, in press).

4. J. B. Ramsay and A. Popolato, "Analysis of Shock Wave and Initiation Data for Solid Explosives," in Proc. Fourth Int. Symp. Detonation, U.S. Naval Ordnance Laboratory, White Oak, 1965 (ONR Rept. ACR-126, 1966), p. 233.

5. R. J. Wasley, R. H. Valentine, and E. J. Nidick, Jr., Designing Flyer Plate/Gun Experiments to Provide Sharp Compressive Shocks and Soft Recovery of Targets, Lawrence Livermore Laboratory, Rept. UCRL-50887 (1970).

6. I. E. Lindstrom, "Plane Shock Initiation of an RDX Plastic-Bonded Explosive," J. Appl. Phys. 37, 4873 (1966).

7. L. G. Green, Lawrence Livermore Laboratory, private communication (1977).

8. Y. de Longueville, C. Fauguignon, and H. Moulard, "Initiation of Several Condensed Explosives by a Given Duration Shock Wave," in Proc. Sixth Int. Symp. Detonation, San Diego, CA, 1976 (ONR, NSWC, LASL, LLL, in press).

9. F. E. Walker and R. J. Wasley, "Critical Energy for Shock Initiation of Heterogeneous Explosives," Explosivstoffe 17, 9 (1969). 